\title{
Give and Take: Public Use as Due Compensation in PruneYard
}

\author{
Lillian R. BeViert
}

I embrace Professor Epstein's notion that it is sensible in approaching takings questions to remain firmly tethered to common law baselines. And it is useful to think of common law rights in property as having originated in individual acts of acquisition, and, at least as a first cut, to think of the state's principal role as being a supplier of legal rules and enforcement mechanisms that protect, maximize the value of, and facilitate private transactions in these bottom-up rights. Indeed, rekindling our awareness of the benign social outcomes that adherence to these common law baselines tends to generate (as well as awakening us to the pervasively malignant consequences of permitting their promiscuous redefinition by the state) is one of Professor Epstein's more important contributions to contemporary debate. But to acknowledge that "common law baselines" are a good starting point for the resolution of takings cases only tells us approximately where to begin, for it is a mistake to speak of "common law baselines" as if there were a readily discoverable, uncontested "there" there.

One of the least noted features of the PruneYard ${ }^{1}$ decision is that it permits state lawmakers to eliminate shopping center owners' rights to exclude political leafleteers but it does not require them to do so. The Court did not necessarily reject Professor Epstein's "common law baselines" approach to takings questions. Instead, it located the baseline slightly to the left of where Epstein thinks it belongs. Considered strictly on its own terms, the case stands for the not very extravagant proposition that the private property rights of shopping center owners do not include an unqualified right to exclude political protesters. Put another way, PruneYard simply holds that it is constitutionally permissible but not constitutionally required for state lawmakers ${ }^{2}$ to de-

$\dagger$ Henry and Grace Doherty Charitable Foundation Professor, University of Virginia Law School. This Article was commissioned for and presented at an American Enterprise Institute conference on legal and economic perspectives on takings held in March 1996.

1 PruneYard Shopping Center v Robins, 447 US 74 (1980).

" Professor Epstein notes, as if it might have mattered, that "state legislatures and city councils [have] played no role in fashioning the rules that allowed political protests to 
cide whether to qualify the right to exclude in the precise way and for the precise purpose that California found compelling.

Professor Epstein would have had the Court decide that, by constitutional definition, "property" includes the absolute right of shopping center owners to exclude political protesters. In this response to Professor Epstein, I suggest that, while a bottom-up approach to the state's power to modify common law rules in takings cases makes considerable sense, the approach itself does not generate such an unequivocal answer to the question presented in PruneYard as Epstein suggests. Recognition of Californian shopping center owners' right to exclude the political protesters was not unquestionably necessary to maintain the integrity of private property by constitutional definition, or at least it was not as unquestionably necessary as the essentialist nature of Epstein's analysis would imply. I also argue that even if one agrees with Epstein that the compromise of the owners' rights to exclude constituted a taking, there are ways of thinking about political activity and about free speech rights that would at least provisionally justify the conclusion that requiring private shopping center owners to permit political pamphleteers might produce large enough social gains to supply the constitutionally required implicit compensation.

\section{THE COMMON LAW AND THE RIGHT TO EXCLUDE}

Professor Epstein concedes that his approach to takings questions requires common law baselines to be stripped for analytical purposes of "most of [their] warts" and "present[ed] . . in a somewhat idealized form." ${ }^{3} \mathrm{He}$ attempts to specify the inquiry's

take place on private property." Richard A. Epstein, Takings, Exclusivity and Speech: The Legacy of PruneYard v Robins, $64 \mathrm{U}$ Chi L Rev 21, 43-44 (1997). The implication is that, were the state legislature to have decided to impose access obligations on shopping center owners, the constitutional issue might have been different. But Epstein's analysis in fact derives none of its momentum from separation of powers or institutional competence concerns. Instead it is completely grounded in his view that the constitutional issue ought to be resolved by properly defining the right to exclude. Several of the state courts that have refused to follow California's lead, however, have relied heavily on their perceived lack of institutional competence accurately to balance the competing interests. See, for example, Woodland v Michigan Citizens Lobby, 423 Mich 188, 378 NW2d 337, 347 (1985) ("[C]ourts are inherently limited, because of their institutional character and role, to accomplish goals which are essentially legislative and political."); Cologne $v$ Westfarms Associates, 192 Conn 48, 469 A2d 1201, 1210 (1984) ("It is not the role of this court to strike precise balances among the fluctuating interests of competing private groups which then become rigidified in the granite of constitutional adjudication. That function has traditionally been performed by the legislature.... $)$.).

3 Epstein, $64 \mathrm{U}$ Chi L Rev at 25 (cited in note 2). 
relevant parameters: because the rights originated from the "bottom-up," the state's function with regard to them is "only to protect [private property], not to destroy it in the name of redefinition or regulation." Moreover, there is a "constant need to define ownership rights to minimize the bargaining breakdowns that result from erecting monopoly blockades." In addition, the rights' substantive contents are subject to two constraints: they must create parity between rights-holding individuals, and they must systematically maximize the value for each party in recurring conflicts. Applying this conceptual framework, Professor Epstein concludes that the common law would have (should have? did?') protected individual property owners' absolute right to exclude, as well as what he takes to be its corollary, the right to admit conditionally.

The conclusion is too facile. Deciding whether any particular rule in fact conforms to Epstein's specifications is neither as uncomplicated nor as uncontroversial as his confident assertions might lead us to believe. In the first place, his specification of the parity constraint ( $A$ cannot exclude $B$ if $B$ cannot exclude $A$ ) would seem to require only that if $A$ and $B$ are similarly situated, their rights to invade one another's interests must be reciprocal and equivalent. It does not necessarily condemn a set of baseline rules that permits $A$ to be treated differently from a differently situated $B$. Nor does it necessarily imply that there are no differences in the situation between $A$ and $B$ that would warrant conceptualizing differently the constitutional minima of their rights to exclude. Professor Epstein seems to claim that at the definitional baseline, there are no differences that would warrant different levels of protection (or regulation) of the right to exclude. But does it really make sense of our legal experience to claim that if $A$ owns a regional shopping center and $B$ owns her own home, the state must-not may but must-secure to each the same right to exclude others from their property as well as, presumably, prescribe similar obligations to those whom they do admit?

It is important to notice that the rule announced in PruneYard effected an across the board modification in California law: henceforth all shopping center owners (but only shopping center

- Id at 26-27.

"Id at 31-32.

" Professor Epstein's exposition does not always make clear whether his "idealization" of the content of common law baselines is normative or descriptive. 
owners $)^{7}$ would be required, on a politically nondiscriminatory basis, to permit political groups to distribute literature on shopping center premises. In contrasting this result to the vindication of the right to exclude that the Court had, with Epstein's approval, effectuated in Kaiser Aetna, ${ }^{8}$ Epstein rather extravagantly characterizes it as working a "conversion of property from wholly private to partially public." $\mathrm{He}$ rejects as manipulative then-Justice Rehnquist's attempt to characterize the shopping center owner as having "consented" to the political activity by virtue of opening the property for the public "to come and go as they please." And apparently because he thinks an "essential" attribute of all property owners' rights is the absolute right to exclude, he chides Justice Rehnquist for seeming to make the contrary claim that the "essence" of a shopping center prevents the invocation of a constitutionally protected right selectively to consent to admit. ${ }^{11}$ Remember, though, that Justice Rehnquist was saying only that the essential nature of shopping centers permits states to prohibit PruneYard's kind of selective admission, not that it requires them to do so. And it is by no means as patently obvious to me as it is to Professor Epstein that reading the Constitution this way-so as to permit states to modify shopping center owners' rights across the board to require them to grant access to political pamphleteers-cuts the heart out of and destroys an "essential attribute of property."

Owners of commercial establishments and places of public accommodation have time out of mind and on a variety of rationales (from preventing monopolistic exploitation ${ }^{12}$ to regulating "businesses affected with a public interest"13) been subjected to different, more stringent, state (and federal) regulations than have owners of, say, single family homes. The former, but not the latter, are broadly subject to nondiscrimination-in-access rules. The duties of care that owners of commercial establishments owe

7 See Robins v PruneYard Shopping Center, 23 Cal 3d 899, 592 P2d 341, 347-48 (1979).

Kaiser Aetna v United States, 444 US 164 (1979).

- Epstein, 64 U Chi L Rev at 36 (cited in note 2).

10 See PruneYard, 447 US at 87.

$"$ Epstein, 64 U Chi L Rev at 38 (cited in note 2).

${ }^{12}$ See, for example, Joseph Story, Commentaries on the Law of Bailments $\$ 476$ (Little, Brown 9th ed 1878) (James Schouler, ed); Bell v Maryland, 378 US 226, 296-300 (1964) (Goldberg concurring) (gathering authorities).

${ }^{13}$ See Munn $v$ Illinois, 94 US 113, 126 (1876), quoting Lord Chief Justice Hale, De Portibus Maris, in Francis Hargrave, ed, A Collection of Tracts Relative to the Law of England 45, 78 (E. Lynch, et al 1787). 
to their invitees are more onerous than those owed by a homeowner to her guests. ${ }^{14}$ These differences in treatment are not required by the Constitution, but surely the fact of the differences itself does not pose a genuine constitutional problem. Indeed, I should think (or should have thought until I read Professor Epstein's paper) that it was uncontroversial to assert that these differences in regulatory regimes do not breach any constraint of "parity" of treatment among property owners, given the quite obvious differences between homes and shopping centers.

Another important point is that, with respect to common law baselines, Epstein's confident assertion of a "basic norm that the government can stabilize, but not destroy, the institutions of common and private ownership"15 begs the all-important question: is "stabilization" vs. "destruction" a definitional or an empirical issue? For example, several well established common law doctrines compromise and coerce uncompensated transfers of the absolute right of individual owners to exclude. Consider, for example, adverse possession, ${ }^{16}$ implied easements, ${ }^{17}$ easements "by estoppel, ${ }^{n 18}$ and "fencing out" rules that require an owner to put up a fence if he expects to recover for damage done by trespassing cattle. ${ }^{19}$ Presumably Professor Epstein does not think that the institutions of private property are destroyed when rules that significantly modify the right to exclude are justified because they encourage early recourse to market transactions or prevent the exploitation of monopoly positions. Thus he countenances the doctrine of adverse possession, ${ }^{20}$ despite the fact that it completely wipes out the original owner's rights (including of course the right to exclude) and transfers them to the possessor without any compensation at all and quite without the owner's consent. Although it might appear otherwise to the dispossessed owner, it could be said that adverse possession does not "destroy" the institution of private ownership but instead "stabilizes" it by clearing titles and creating incentives for owners to make their claims

"Restatement (Second) of Torts $\$ \S 332,341-43$ (1965).

"Epstein, 64 U Chi L Rev at 32 (cited in note 2).

${ }^{16}$ Restatement of Property $\$ \S 457-65$ (1944).

"Id at $\$ \S 474-76$.

${ }^{1 *}$ Id at $\$ 519(4)$.

${ }^{19}$ Restatement (Second) of Torts $\$ 504(4)$ (1977).

${ }^{20}$ Richard A. Epstein, Past and Future: The Temporal Dimension in the Law of Property, 64 Wash U L Q 667, 679 (1986) (comparing general statute of limitations on land to eminent domain, and asking whether removal of some rights based on first possession can be justified by an increase in the overall utility to the individuals involved). 
known to occupiers sooner rather than later. Moreover, the doctrines of implied easements and easements by estoppel, despite the fact that both effectuate coerced, uncompensated and often quite unintended transfers ${ }^{21}$ of a portion of the right to exclude from servient to dominant owners, do not so much "destroy" the right to exclude as they "stabilize" ownership by eliminating bilateral monopolies that would emerge were the servient owner's rights held to survive.

Thus, it might be true by definition that the right to exclude is an essential feature of property ownership, and it does indeed seem quite "difficult to conceive of any property as private if the right to exclude is rejected." ${ }^{22}$ It does also seem to be true-at least if "routinely" means "usually but not always"-that at common law "ownership is routinely protected by a strong 'property rule' prohibiting purposive dispossession." ${ }^{\prime 23}$ Still, as a descriptive matter, it is not a fact that by definition common law baselines protect the right to exclude absolutely, always and everywhere (except against entrance dictated by the necessity to escape imminent peril). Nor does it seem to be true that these failures to protect the right to exclude "destroy" the institution of private property despite the fact that, for some owners sometimes, they destroy it utterly.

\section{THE SOCIAL GAINS OF PRUNEYARD}

Whether or not the foregoing analysis is persuasive, it is illuminating to look at PruneYard in a more complete legal and historical context than Professor Epstein provides. Two facts in particular stand out. First, publicly owned streets and sidewalks have always been ("time "out of mind" in Justice Roberts's phrase ${ }^{24}$ )-and are constitutionally required to be-fora for political activity of the kind in which the teenagers at the Prune-

\footnotetext{
21 "Once an owner has the right to exclude, then the ability to set the term and conditions of admission should lead to the optimal use of the resource for all the parties involved," asserts Professor Epstein. Epstein, 64 U Chi I Rev at 31 (cited in note 2). The doctrine of licenses (which by definition include the condition of revocability) that become easements by estoppel (which by definition are irrevocable), see Allee $v$ Kirk, 602 SW2d 922, 925 (Mo Ct App 1980); Restatement of Property \$ 519(4) \& comment g (1944), belies Epstein's implication that the common law universally protects, as part of the absolute right to exclude, a right to include on conditions set by the owner.

${ }^{22}$ Epstein, $64 \mathrm{U}$ Chi L Rev at 22 (cited in note 2).

$\approx$ Id at 33 .

${ }^{24}$ Hague v Committee for Industrial Organization, 307 US 496, 515 (1939) (Roberts opinion).
} 
Yard center wished to engage. This suggests that, despite the protestations of those who manage such places, shopping centers have long accommodated themselves to a variety of uses; put another way, it suggests that permitting expressive activity there does not fatally undermine and is not incompatible with their "primary use." Second, the modern privately owned shopping center-The Mall-is, in important respects and for better or worse, ${ }^{25}$ the "functional equivalent" ${ }^{26}$ of the publicly owned downtown streets. Most relevant to the claimants in PruneYard, it is the place where pamphleteers are likely to find people to receive their pamphlets. In a line of cases beginning with Marsh $v$ Alabama ${ }^{27}$ and brought to a definitive end in Hudgens $v N L R B,{ }^{28}$ the Court flirted with a reading of the Constitution that would have required private shopping centers to permit political activity within their confines, thus turning "functional equivalency" into "constitutional equivalency." They resisted this temptation, opting instead in PruneYard for a constitutional interpretation that replaces must with may, an interpretation that allows states to conclude that since shopping center owners have in effect privatized the formerly public square, it is reasonable to ask them to accommodate some of the political activities that the public square formerly absorbed.

Title II, the public accommodations section of the Civil Rights Act of $1964,{ }^{29}$ requires owners of public accommodations to serve patrons on a racially nondiscriminatory basis despite owners' unwillingness to do so. The Act takes away the right formerly enjoyed by the owners "to select the persons whom they admit and the purposes for which they are admitted." ${ }^{30}$ The Court sustained it against a constitutional challenge based inter alia on the claim that it deprived owners of "property" under the Fifth Amendment. ${ }^{31}$ Professor Epstein does not appear to question the Court's holding in this regard. By a parity of reasoning, I

¿ Professor Michelman clearly thinks it's for worse. Frank Michelman, The Common law Baseline and Restitution for the Lost Commons: A Reply to Professor Epstein, $64 \mathrm{U}$ Chi L Rev 57, 66 (1997).

$\because$ Hudgens $v$ NLRB, 424 US 507, 520 (1976) (comparing malls to municipalities, and hypothesizing their equivalence).

${ }^{27} 326$ US 501, 508-09 (1946) (recognizing the right to distribute religious literature in a company-owned town).

$\approx 424$ US at 520-21 (denying a First Amendment right to picket in a shopping center parking lot).

* 42 USC $\$ \$ 2000$ (a) et seq (1994).

Epstein, 64 U Chi L Rev at 37 (cited in note 2).

${ }^{31}$ See Heart of Atlanta Motel, Inc $v$ United States, 379 US 241, 258, 260-61 (1964). 
should think he might come to the same conclusion regarding PruneYard's conclusion that a state's decision to deprive shopping center owners of formerly enjoyed rights "to select" ${ }^{32}$ does not deprive the owners of "property." The interests served and the benefits surely attained by banning racial discrimination in public accommodations are admittedly different from and, certainly at the time Title II was passed, no doubt more in need of legal support than the interests served and the certainty of benefits attained by requiring admission of political pamphleteers. But this observation goes only to whether the respective rules are rationally related to their stated objectives, not to the question of whether in doing so they take property. With respect to the takings issue-the important question for present purposes-both rules run similarly roughshod over the respective owners' absolute right to exclude. Title II turns public accommodations into commons for trade; PruneYard permits states to turn shopping malls into commons for pamphleteers. Neither would have been necessary if property owners' willing consent had initially been forthcoming.

In Forbidden Grounds, Professor Epstein finesses this point, ${ }^{33}$ just as he seems to do in his commentary on PruneYard. He defends Title II by seeming to claim that all the shop, restaurant, and hotel owners who seemed to be putting up such a fight against the Act had in fact really wanted to integrate their operations even before it was enacted but found themselves powerless against the dark and evil forces (none of whom, presumably, owned public accommodations) that were then arrayed against integration. ${ }^{34}$ And, he claims, those who refused to comply when Title II was first enacted were themselves "eager to obey"35 but found themselves "set upon by gangs of racists." Thus Epstein supplies the "owner consent" he needs in order to convince himself that Title II did not destroy an essential element of property by the simple expedient of asserting that "the deviation between what the statute requires and what people want is too small to be of any consequence." ${ }^{37}$

\footnotetext{
${ }^{32}$ Epstein, 64 U Chi L Rev at 37 (cited in note 2).

${ }^{33}$ Richard A. Epstein, Forbidden Grounds: The Case Against Employment Discrimination Laws 126-29 (Harvard 1992).

is Id at 127-28.

${ }^{35}$ Id at 127.

${ }^{35}$ Id.

${ }^{37}$ Id at 128. Epstein is correct, of course, that Title II has been an almost unqualified success at achieving its goal of securing nondiscriminatory access to public accommoda-
} 
But even if Title II had been found to destroy an essential attribute of property, it might well have supplied sufficient implicit compensation to have satisfied the Epsteinian formula. One could reach this conclusion by one of two routes. First, because Title II solved a pervasive collective action problem that previously had posed a significant impediment to individual efforts to integrate public accommodations, it in fact did not have a significant negative effect on the wealth of the affected owners-at least if one is willing to value at close to nil the wealth effect that their loss of freedom to exclude might have had. Or, second, one could claim that the particular alteration in the system of property rights represented by the public accommodations title was justified because it was an alteration that promised huge overall gains for society at large, and these gains supply whatever "compensation" is needed for the sacrifice by the property owners of this particular stick in their bundle of rights.

Analogous lines of argument are available, in principle, ${ }^{38}$ to justify the alteration of rights in PruneYard. First, a collective action problem might well contribute to the unwillingness of shopping center owners to allow politicking within their borders. Each might reason, "If I'm the only mall owner that lets those pests in, I'll lose business because the shoppers who would prefer

tions. To the surprise of many contemporary observers, it turned out to be practically self-enforcing, and thus did not require the massive, obtrusive federal presence that had been predicted and feared.

Professor Epstein thinks that I am worried that "if PruneYard falls, then the public accommodations provisions of Title II of the Civil Rights Act of 1964 will fall as well." Epstein, $64 \mathrm{U}$ Chi L Rev at 46 (cited in note 2) (citation omitted). He offers words of consolation: "if Title II were scrapped tomorrow, shopping center owners would scramble to proclaim to the world that all persons were welcome into their malls regardless of race or sex." Id at 47. I agree with that view, but it is beside the point here. I am concerned about scrapping PruneYard as a matter of constitutional principle, because the constitutional principle for which it stands provided needed support to Title II at the time that it needed constitutional sanction to overcome property owners' objections to nondiscrimination. The constitutional principle cannot be supplied by his effort to supply nunc pro tunc owner consent that did not in fact exist before.

Epstein does not like the Americans with Disabilities Act (ADA), 42 USC $\$ 12101$ et seq (1994), and seems willing to scrap Title II now (because we no longer need it) in order to take the constitutional pins out from under it. But Title II would have to have been found unconstitutional at the time it was passed in order not to have set in motion the inexorable expansion of the nondiscrimination principle into the equal access regardless of cost" principle that has taken hold of late. See Epstein, $64 \mathrm{U}$ Chi L Rev at 47 (cited in note 2).

${ }^{3 *}$ As Epstein appears to concede, see Epstein, $64 \mathrm{U}$ Chi L Rev at 45 (cited in note 2). Whether the collective action argument has as much factual support as it had in the case of Title II is admittedly open to question, but the agnosticism implicit in PruneYard permits lawmakers to accept it even without overwhelming factual support. 
not to be bothered by them-which probably means most shoppers-will go to other malls. If state law requires them to be allowed into all the malls, then at least I won't suffer a particularized competitive loss. And shoppers will no doubt get used to it, just as people downtown have done." States following PruneYard solve this collective action problem, thus eliminating a large chunk of the feared individualized monetary loss. Nuisance damages amounting to the cost of drafting and administering time, place, and manner rules might remain; but although there is the question of whether we should let states evade an obligation to compensate in principle by citing the difficulty of estimating this loss, it is likely to be true that the cost of quantifying it would devour the compensatory benefit from doing so.

Second, an argument for PruneYard's alteration of basic rights is that it may well have produced large enough overall social gains to supply the needed compensation. The argument would run as follows. A viable democracy requires a politically well informed, active, and engaged citizenry. Citizens who do not know or care what their elected representatives are doing cannot act as responsible voters when they are called upon at election time to hold their agents to account. Citizens who know and care about what their government is doing are indispensable to government accountability. Asymmetries of information between citizens and government officials present the latter with opportunities to shirk their duties to the citizenry as a whole and to pursue their own-or some special interest group's-ends instead. The more citizens know and understand what their government is doing, the more likely it is that they will detect its shirking. And the more they care about the shirking that they do detect, the more likely they will be to find ways to deter it and to punish it when it happens, and the easier they will find it to hold their government accountable.

Yet, although the value to a democratic society of a well informed, engaged citizenry is great, private citizens appear to have systematic incentives to engage in less political activity than the social value of such activity would warrant. This is in part because of the "public good" nature of government accountability: the benefits (or costs) of an accountable (or of a shirking) government will accrue to all citizens whether or not they are politically active or informed. Although none can be excluded from enjoying the benefits of alert citizen monitoring, the costs of becoming knowledgeable about government and of being politi- 
cally active will be borne only by those individuals who choose to incur them. Many persons will rationally choose not to do so, preferring instead to free ride on the monitoring efforts of their fellow citizens. In addition, if the value of private political activity is assumed to derive to any substantial degree from the appropriable expected value of the activity as an input to voting, it is somewhat surprising that anybody engages in any political activity at all. Considered as an act whose aim is to affect the outcome of an election, voting itself has negative expected value: the costs of voting are always positive but the chance that any one individual's vote will affect the outcome of an election is almost always minuscule. Thus, relative to the number who are eligible to do so, few citizens can be expected to vote. Even fewer, accordingly, can be expected to incur the costs of becoming politically active and well-informed.

The implication of this analysis for the PruneYard problem is clear. Precisely because those who engage in political activity, like the pamphleteers in private shopping centers, cannot internalize all the social benefits that their behavior produces, a rule that allows them to externalize some of their costs-by requiring shopping center owners to provide them with a forum-will cause more people to engage in more of the activity, to the very great benefit of all citizens. ${ }^{39}$

This argument for the PruneYard result admittedly requires that one embrace the not universally accepted premise that rules with respect to freedom of expression ought to be crafted so as to enhance speech opportunities. ${ }^{40}$ This view is not the only possible way to look at free speech guarantees. One who thought, for example, that these guarantees were designed to constrain government from deliberately distorting public debate, by threatening to punish those who criticize it, by selectively regulating

Compare Daniel A. Farber, Free Speech Without Romance: Public Choice and the First Amendment, 105 Harv L Rev 554, 559 (1991) (arguing that "if the government intervenes in the market at all, it should subsidize speech rather than limit it"); Richard A. Posner, Free Speech in an Economic Perspective, 20 Suffolk U L Rev 1, 20 (1986) (commenting that "if it is true that the main benefits of information are external, anything that raises the costs of producing information is questionable on its face ... [and] a frequent common law response to the problem of external benefits is to allow the enterprise to externalize some of its costs").

${ }^{4}$ Compare Lillian R. BeVier, Rehabilitating Public Forum Doctrine: In Defense of Categories, 1992 S Ct Rev 79, 101 (describing the "[e]nhancement model" of free speech, which inter alia "imposes affirmative duties on government to maximize the opportunities for expression"). 
speakers according to the point of view they espouse, or by somehow devising means of stacking the political deck, ${ }^{41}$ would not be inclined to force private parties to provide a subsidy along the lines of PruneYard.

This brief reply to Professor Epstein is not the place to choose sides on the issue. Suffice it to say that the "enhancement model" of free speech represents at least a plausible and coherent account, and that one of its policy implications is state-mandated private subsidies for expressive conduct. Professor Epstein finesses the argument, simply asserting that we do not need to subsidize political activity, because "[t]he forces of competition will make sure that the gains from all beneficial transactions are captured." ${ }^{\prime 2}$ But if it is true, as many people seem to think, that when it comes to political speech the forces of competition do not make the right calculation of what those gains are, then the rule announced in PruneYard may well yield net social benefits.

\footnotetext{
${ }^{11}$ Id at 102 (The First Amendment only constrains government actors and enforces government neutrality.).

${ }^{2}$ Epstein, 64 U Chi L Rev at 52 (cited in note 2).
} 